\title{
BUMDES Management Training in Sei Bamban District Based on Cognitive Cointegration Method
}

\author{
Lilinesia $^{1)}$, Yenni Mariani Sinurat ${ }^{2)}$, Rodi Syafrizal ${ }^{3) *}$, Rico Nur Ilham ${ }^{4)}$ \\ 1,2,3 Bina Karya Tebing Tinggi College of Economics \\ E-mail: lilinesia@gmail.com, yennisinurat@gmail.com, \\ rodisyafrizal@gnail.com \\ ${ }^{4}$ Faculty of Economics and Business, Malikussaleh University \\ E-mail: riconurilham@unimal.ac.id
}

\begin{abstract}
Currently the government continues to strive to build and develop the economy of rural areas through community empowerment programs with the aim of increasing productivity, business diversity and regional potential with the aim of improving the economy and welfare of rural communities. One of the government programs is by providing a budget. Funds in the field of community empowerment are used to support capital for the formation of Village Owned Enterprises (BUMDes). Where in accordance with the objectives of BUMDes, namely optimizing the management of village assets and the potential of existing villages, to support the village economy, and improve the welfare of the village community. But unfortunately, until now the role and function of my BUMDes has not been effective and cannot be felt by the community. This is due to the incompetence and lack of professionalism of human resources managing BUMDes and the lack of integration of the businesses managed by BUMDes with the existing village potential so that it seems as if BUMDes stands only as a formality without supporting the economic potential of rural communities. The purpose of this study is to create a strategic concept in the management of BUMDes so that it runs more effectively and according to targets so that it can support the economy of rural communities through the development of human resource knowledge in managing BUMDes that is integrated with the economic potential of rural communities. So that BUMDes and Village Basic Pontesials are integrated in a business institution that supports the village economy for the welfare of the village community. This solution can help rural communities in strengthening their economy and provide knowledge views and open insight to BUMDes managers so that they can develop BUMDes into businesses that are in synergy with the community. This study uses primary data sourced from questionnaires and interviews aimed at BUMDes management employees to see the extent to which the abilities, expertise, and knowledge of BUMDes management employees can evaluate and innovate in the business.
\end{abstract}

Keywords: BUMDes, HR, Welfare

\section{PRELIMINARY}

Currently, rural economic growth is still considered slow compared to urban economic development, this is due to monotonous economic development. Therefore, the government continues to strive to improve the welfare of rural communities through the use of the State Revenue and Expenditure Budget (APBN) in village development which is then referred to as village funds. Where the use of village funds must be in accordance with the direction of the Regulation of the Minister of Villages, in the Development of Disadvantaged Regions and Transmigration (PDTT) Number 16 of 2018 concerning Priorities for the Use of Village Funds in 2018. 
2019 article 10 paragraph 2i, provides an explanation of the use of village funds in the field of community empowerment to support capital for the formation of Village Owned Enterprises (BUMDes) (PERMEN, 2018).

The presence of BUMDes is expected to make the village more independent and the community to be more prosperous. BUMDes functions as a driving force for the village economy, a business institution that generates Village Original Income (PADes), as well as a means to encourage the acceleration of improving the welfare of rural communities. Where BUMDes acts as an umbrella institution in overshadowing the potential of villages and community business activities to be more effective and productive. (Coristya, Heru \& Suwondo 2013).[2]

The establishment of BUMDes is so firmly carried out and it is known that by 2017 more than 22,000 villages had BUMDes, but less than $20 \%$ of BUMDes were active. The formation of BUMDes in villages seems only as a formality because it has not been seen to play an active role in achieving the goals of establishing BUMDes itself. Some of the obstacles for BUMDes in starting a business are the lack of business capital which can make BUMDes unable to carry out business diversification, the absence of adequate human resources in the management of BUMDes, so that institutional performance is not optimal, and lastly in institutional aspects, the level of public awareness and knowledge of BUMDes is still low (Agung, 2016).[3]

Some of the problems that occur in the management of BUMDes, including: (a) lack of community participation in the management of BUMDes, (b) the village government is not maximally empowering the community to develop BUMDes, (c) BUMDes is not running, (d) lack of human resources (HR). ) adequate management of BUMDes, and (e) lack of public awareness in developing other business fields. (Nursetiawan, 2018).[4]

Constraints in the management of BUMDes cannot be separated from the inadequate role of human resources. So that the functions and objectives of BUMDes are still far from being effective. Even though the formation of BUMDes has been in accordance with the procedures set out in the village ministerial regulations through village meetings, the skills of existing human resources do not understand the technical implementation of BUMDes which results in the unfocused implementation of BUMDes operations and the absence of an entrepreneurial spirit, making BUMDes employees experience difficulties in implementing BUMDes. management (Ulul Hidayah, 2019). [5]

It can be concluded that the role of human resources is important in the management of BUMDes because it is necessary to develop Cognitive HR who are able to see the original potential of the village (Basic Potential) that exists to be developed through BUMDes. Because each village has different potentials, both geographically, culturally, and sources of income for the village community, it is necessary to handle and specifically in each village so that the business managed by BUMDes is in line with the original potential of the village which directly overshadows the potential and business of the community. village. For this reason, of course, it is necessary to evaluate the performance of HR in the management of BUMDes in order to achieve the goals and functions of BUMDes as a forum for the village community's economy.

\section{THEORETICAL STUDY}

Other theories that will be supported are as follows:

\section{Village Autonomy}

Based on Law Number 6 of 2014 concerning Villages Article 1 paragraph (1) it is stated that, the Village as a legal community unit that has territorial boundaries is authorized to regulate and manage government affairs, the interests of the local community based on community initiatives, cultural rights that are recognized and respected in the government system of the Unitary State of the Republic of Indonesia. This PP explicitly acknowledges the existence of village autonomy within the framework of the Unitary State of the Republic of Indonesia. The PP also 
gives considerable authority to the village head in carrying out his duties as the head of the village government. (Coristya Berlian Ramadana, 2013)[2]. Thus, the village government must play an independent role in managing the potential of the village so that it can prosper the economy of its citizens.

\section{Basic Potential Village}

In basic terminology, village potential can be interpreted as the original potential of the village or the basic capabilities possessed by each village and have certain uniqueness, both geographically, human resources, and culture that can become a symbol of the village. Village potential can be divided into two; The first is the physical potential in the form of land, water, climate, geographical environment, livestock, and human resources. The second is the nonphysical potential in the form of the community with its patterns and interactions, social institutions, educational institutions, village social organizations, and village officials and civil servants. (Soleh, 2017) [6].

The village development strategy must be carried out comprehensively with the various potentials it has. The quality of village human resources also needs to be continuously improved with various programs and assistance. (Chikamawati, 2015) [7]. Based on that assumption, the existence of the village should get serious attention from the central government by creating policies related to economic empowerment which are carried out by collecting and institutionalizing community economic activities. (Zulkarnaen, 2016) [8]. The village development strategy must be carried out comprehensively with the various potentials it has. The quality of village human resources also needs to be continuously improved with various programs and assistance. (Chikamawati, 2015) [7].

\section{The Role of BUMDes in Improving the Village Economy}

BUMDes is a village business entity that was established with the aim of optimizing the management of existing village assets, advancing the village economy, and improving the welfare of rural communities. And the function of BUMDes is as a driving force for the village economy, as a business institution that generates Village Original Income (PADes), as well as a means to encourage the acceleration of improving the welfare of rural communities. With the presence of BUMDes, it is hoped that the village will become more independent, and the community will become more prosperous. (Dewi, 2014) [9]. As a center for the village economy, it is hoped that BUMDes will have a role in sustainable village development, empowering rural communities, and improving the village economy. The roles of BUMDes include:
a. village potential identification
b. village leading business mapping
c. build an integrated economic center
d. market superior village products. (Chikamawati, 2015) [7].

\section{Human Resource Development}

Human Resources (HR) is the main potential in village economic development. Village communities that are still viewed as underdeveloped communities must be built based on the ability and quality of human resources. Because the abundance of potential wealth resources owned by the village will not be able to encourage village progress towards the welfare of the village community without the management of quality human resources. It is therefore important to improve the quality of rural human resources. Community development can be done through mentoring, counseling, empowerment, and education based on implementation and implementation that fosters an entrepreneurial spirit. Well identified village potential, then managed to become something of a higher quality and carried out by reliable human resources, it 
can be ensured that sustainable village development will automatically build, and prosperity can be achieved. (Chikamawati, 2015) [7].

\section{e. BUMDES Management Strategy}

Village development is an effort to improve the standard of living and welfare of rural communities. Where in the implementation of village development a strategy is needed to achieve progressive and of course sustainable goals. (Nursetiawan, 2018) [4]. In general, the purpose of developing village potential is to encourage the realization of village community independence through the development of superior potential and institutional strengthening and community empowerment. The following are the steps in developing village potential so that it runs smoothly, effectively and efficiently in accordance with existing potential and community needs:

1. To record and review the available potential data to determine the objects that can be developed.

2. Conduct field surveys to collect data that will be used as material in mapping potentials and problems as well as facilitation that will be implemented.

3. Conducting an assessment through tabulation and analysis of the collected data using a predetermined analytical method.

4. Determine the priority scale of the potential to be developed based on the needs, costs and benefits of the development results.

5. Formulate a design or strategic plan that is oriented towards community empowerment to "develop an independent village based on rural areas" based on real conditions in the field.

6. Implement the design or strategic plan that has been produced (Soleh, 2017).

However, the strategy for solving rural economic problems is not enough, only focusing on village resources and potentials because human resource development has an important role in the implementation of achieving these goals. Human Resources are the most important potential in village economic development. Because the empowerment of village potential will not develop if the resourceshuman and empowerment is not done. (Chikamawati, 2015) [7].

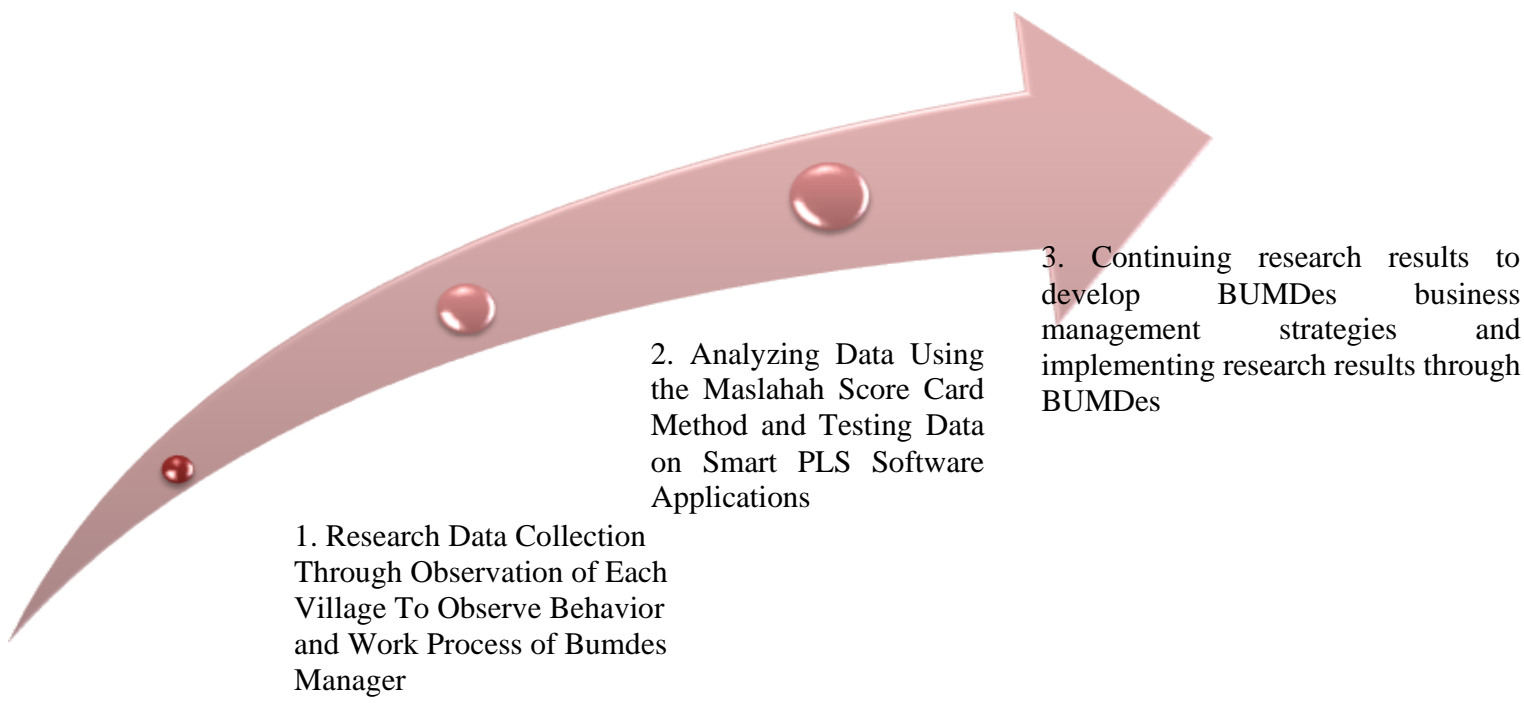

Figure 1. Road Map of Research on Cognitive Analysis of Basic Potential Integration Village in Bumdes Manager 


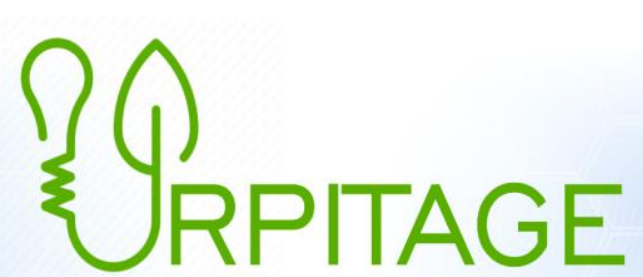

International ReView of Practical InNovation, Technology AND Green EnERgy

\section{METHOD}

The research method used in this research is the Mixed Method, which combines the quantitative approach used to analyze statistical data and descriptive qualitative data is used to describe the data and information by analyzing existing theories. The population of this study were all BUMDes Managers in Sei Bamban District, Serdang Bedagai Regency in North Sumatra Province, totaling 30 people. The type of data used in this research is primary data obtained from interviews and questionnaires conducted by inviting resource persons from academics who are experts in the field of entrepreneurship and the Related Offices in Serdang Bedagai Regency as well as BUMDes managers who have successfully developed BUMDes as references and motivations for BUMDes managers. . This study uses primary data obtained from interviews and questionnaires which were tested statistically on the smart PLs software application which was then analyzed through the maslahah scorecard method. The following are the stages of implementation in this research and can be seen in the following flow chart:

Figure 2. Research Flowchart

Data collection The research was carried out through interviews and giving questionnaires to the management party

The lead researcher designed interviews and questionnaires
Members coordinate the BUMDes management as expert Judgment

Conducting interviews and giving questionnaires, further discussions were held with BUM managersDes

The lead researcher becomes the moderator and arranges the flow of interviews and discussions
Research members coordinate the venue to ensure activities run smoothly and conducive

Implementation of entrepreneurship training and procedures for managing BUMDes

The lead researcher becomes a resource person with the performance training of BUMDes Managers

Research members survey and record BUMDes which can be used as samples to conduct coachingtraining to increase village opinion, encourage the community's economy

\section{RESULTS}

Based on the results of the questionnaire that has been answered by the respondents, it is described in general terms

by using a descriptive statistical model. The data displayed is the number of frequency percentages and the acquisition of scores for each indicator to determine the category of effectiveness assessment each variable. 
BUMDES Management Training in Sei Bamban District Based on Cognitive Cointegration Method Lilinesia, Yenni Mariani Sinurat, Rodi Syafrizal, Rico Nur Ilham

Table 4.1 Cognitive Aspects of HR

\begin{tabular}{|c|c|c|c|c|c|c|c|c|}
\hline \multirow[t]{2}{*}{ No } & \multirow[t]{2}{*}{ Instrument } & \multicolumn{5}{|c|}{ Category } & \multirow[b]{2}{*}{$\begin{array}{l}\text { Total } \\
\text { Score }\end{array}$} & \multirow[t]{2}{*}{ Criteria } \\
\hline & & $\begin{array}{l}1 \\
(20 \%)\end{array}$ & $\begin{array}{l}2 \\
(40 \%)\end{array}$ & $\begin{array}{l}3 \\
(60 \%)\end{array}$ & $\begin{array}{l}4 \\
(80 \%)\end{array}$ & $\begin{array}{l}5 \\
(100 \%)\end{array}$ & & \\
\hline \multirow[t]{2}{*}{1} & \multirow{2}{*}{$\begin{array}{l}\text { We apply the basic potential of the } \\
\text { village to adjust the conditions and } \\
\text { potentials that exist in the village in the } \\
\text { management of BUMDes }\end{array}$} & 0 & 5 & 3 & 20 & 2 & 21.8 & \multirow[t]{2}{*}{ Well } \\
\hline & & 0 & 2 & 1.8 & 16 & 2 & $72.6 \%$ & \\
\hline \multirow[t]{2}{*}{2} & \multirow{2}{*}{$\begin{array}{l}\text { I understand the current situation in the } \\
\text { village, including the community, } \\
\text { culture and existing resources. }\end{array}$} & 0 & 3 & 0 & 18 & 9 & 24.6 & \multirow[t]{2}{*}{ Well } \\
\hline & & 0 & 1.2 & 0 & 14.4 & 9 & $82 \%$ & \\
\hline \multirow[t]{2}{*}{3} & \multirow{2}{*}{$\begin{array}{l}\text { We analyze the needs and needs of } \\
\text { today's society. }\end{array}$} & 0 & 2 & 4 & 16 & 8 & 24 & \multirow[t]{2}{*}{ Well } \\
\hline & & 0 & 0.8 & 2.4 & 12.8 & 8 & $80 \%$ & \\
\hline \multirow[t]{2}{*}{4} & \multirow{2}{*}{$\begin{array}{l}\text { I know the potentials of the village in } \\
\text { terms of natural resources, culture and } \\
\text { geographical location. }\end{array}$} & 0 & 2 & 2 & 13 & 13 & 25.4 & \multirow{2}{*}{ Well } \\
\hline & & 0 & 0.8 & 1.2 & 10.4 & 13 & $84.6 \%$ & \\
\hline \multirow[t]{2}{*}{5} & \multirow{2}{*}{$\begin{array}{l}\text { We evaluate the current } \\
\text { performance and achievements of } \\
\text { BUMDes. }\end{array}$} & 2 & 3 & 16 & 7 & 2 & 18.8 & \multirow[t]{2}{*}{ Well } \\
\hline & & 0.4 & 1.2 & 9.6 & 5.6 & 2 & & \\
\hline \multicolumn{7}{|c|}{ Average } & 76.36 & Well \\
\hline
\end{tabular}

Based on the indicators above, it can be interpreted that BUMDes employees in the Sei Bamban district have a good cognitive aspect. Because the results of the mean score of the instrument from the hereditary variable of $76.36 \%$ which is included in the effective category because it is $>60 \%$.

Table 4.2 Maslahah Performance

\begin{tabular}{|c|c|c|c|c|c|c|c|c|}
\hline \multirow[t]{2}{*}{ No } & \multirow[t]{2}{*}{ Instrument } & \multicolumn{5}{|c|}{ Category } & \multirow{2}{*}{$\begin{array}{l}\text { Total } \\
\text { Score }\end{array}$} & \multirow[t]{2}{*}{ Criteria } \\
\hline & & $\begin{array}{l}1 \\
(20 \%)\end{array}$ & $\begin{array}{l}2 \\
(40 \%)\end{array}$ & $\begin{array}{l}3 \\
(60 \%)\end{array}$ & $\begin{array}{l}4 \\
(80 \%) \\
\end{array}$ & $\begin{array}{l}5 \\
(100 \%)\end{array}$ & & \\
\hline \multirow[t]{2}{*}{1} & \multirow{2}{*}{$\begin{array}{l}\text { BUMDes participates and is active in } \\
\text { the implementation of social activities }\end{array}$} & 2 & 0 & 12 & 11 & 5 & 21.4 & \multirow[t]{2}{*}{ Effective } \\
\hline & & 0.4 & 0 & 7.2 & 8.8 & 5 & $71.3 \%$ & \\
\hline \multirow[t]{2}{*}{2} & \multirow{2}{*}{$\begin{array}{l}\text { BUMDes has a work system and } \\
\text { facilities that meet the implementation } \\
\text { of business orientation. }\end{array}$} & 0 & 2 & 6 & 17 & 5 & 23 & \multirow[t]{2}{*}{ Effective } \\
\hline & & 0 & 0.8 & 3.6 & 13.6 & 5 & $76.6 \%$ & \\
\hline \multirow[t]{2}{*}{3} & \multirow{2}{*}{$\begin{array}{l}\text { There are awards received from the } \\
\text { community or local government } \\
\text { regarding the performance of BUMDes. }\end{array}$} & 2 & 0 & 13 & 9 & 6 & 21.4 & \multirow[t]{2}{*}{ Effective } \\
\hline & & 0.4 & 0 & 7.8 & 7.2 & 6 & $71.3 \%$ & \\
\hline \multirow[t]{2}{*}{4} & \multirow{2}{*}{$\begin{array}{l}\text { Making efforts to develop the business } \\
\text { sector and improve the skills of } \\
\text { BUMDes employees }\end{array}$} & 2 & 0 & 5 & 17 & 6 & 23 & \multirow[t]{2}{*}{ Effective } \\
\hline & & 0.4 & 0 & 3 & 13.6 & 6 & $76.6 \%$ & \\
\hline \multirow[t]{2}{*}{5} & \multirow{2}{*}{$\begin{array}{l}\text { BUMDes are able to properly } \\
\text { manage the assets and potentials of } \\
\text { the village }\end{array}$} & 2 & 1 & 8 & 11 & 8 & 18.2 & \multirow[t]{2}{*}{ Effective } \\
\hline & & 0.4 & 0.4 & 0.6 & 8.8 & 8 & $60.6 \%$ & \\
\hline
\end{tabular}




\section{$\hat{\vartheta}_{\text {RPITAGE }}$}

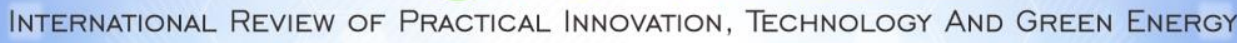

\begin{tabular}{|l|l|l|}
\hline Average & $\begin{array}{l}\mathbf{7 1 . 2 8} \\
\boldsymbol{\%}\end{array}$ & Effective \\
\hline
\end{tabular}

Based on the indicators above, it can be interpreted that BUMDes employees in the Sei Bamban district have good problem performance. Because the results of the mean score of the instrument from the hereditary variable of $71.28 \%$ which is included in the effective category because it is $>60 \%$.

2). Analysis of the Measurement Model (Outer Model)

a). Outer Loading

Figure 4.1 Outer loading value

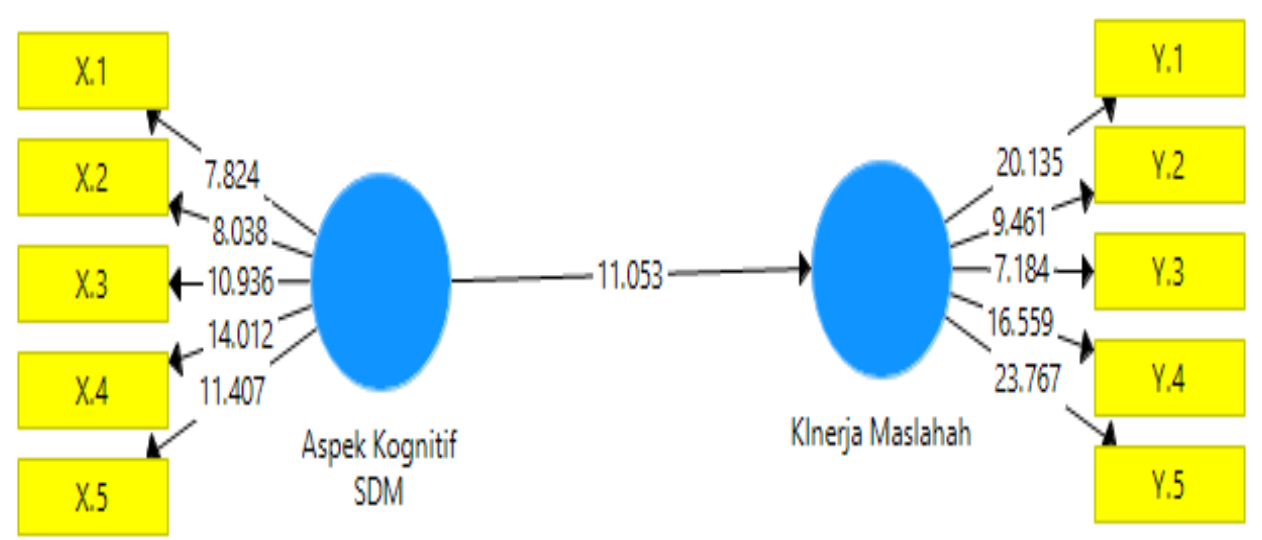

Source: 2021 primary data processed from SmartPLS 3.

From the picture above, it can be seen that all the items that become indicators of each of the variables in this study have a factor loading value above 0.7. Therefore, all of these items deserve to be used as indicators in this study.

Furthermore, all the items that are used as measuring instruments in this study will be explained in the following table 4.10 outer loading:

2). Construct Validity and Reliability

Table 4.4 Construct Validity and Reliability

\begin{tabular}{|c|c|c|c|c|}
\hline $\begin{array}{c}\text { Variabl } \\
\text { e }\end{array}$ & $\begin{array}{c}\text { Cronbach } \\
\text { 's Alpha }\end{array}$ & $\boldsymbol{A}^{\text {Rho_ }}$ & $\begin{array}{c}\text { Composi } \\
\text { te Reliability }\end{array}$ & $\begin{array}{c}\text { Average Variance } \\
\text { Extracted (AVE) }\end{array}$ \\
\hline $\begin{array}{c}\text { Cogniti } \\
\text { ve Aspect }\end{array}$ & 0.902 & 0.909 & 0.927 & 0.719 \\
\hline $\begin{array}{c}\text { Maslaha } \\
\text { h Performance }\end{array}$ & 0.929 & 0.933 & 0.946 & 0.779 \\
\hline
\end{tabular}

Source: 2021 primary data processed from SmartPLS 3.

The table above shows the criteria for validity and reliability because they have met the criteria and requirements in testing the validity and reliability of the construct. Where is the valueCronbach's Alpha, Rho A and Composite Reliability aspects of cognitive and performance maslahah are greater than 0.7 and the Average Variance Extracted (AVE) value is greater than 0.5. Thus the data that has been distributed can be trusted and can be used as data to answer research questions.

3). Structural Model Analysis (Inner Model)

Furthermore, the structural model or inner model is a data analysis model that describes the relationship between latent variables (constructs). namely exogenous and endogenous and the relationship 
between them. The evaluation of the inner model in this study was carried out in 2 ways, namely by looking at the R-Square and F-Square which can be interpreted as follows:

1). R-Square

Table 4.5 Table R Square

\begin{tabular}{|c|r|c|}
\hline Variable & $\begin{array}{r}\text { R } \\
\text { Square }\end{array}$ & $\begin{array}{c}\text { R Square } \\
\text { Adjusted }\end{array}$ \\
\hline $\mathrm{Y}$ & 0.749 & 0.740 \\
\hline
\end{tabular}

Source: 2021 primary data processed from SmartPLS

The table above explains that the R-Square Adjusted path model in this study $=0.740$. meaning that the ability of the Cognitive Aspects of HR in explaining Maslahah Performance is 74\%. Thus the model is classified as Substantial (strong). The image of the R-Square bar chart is as follows:

\section{Figure 4.2}

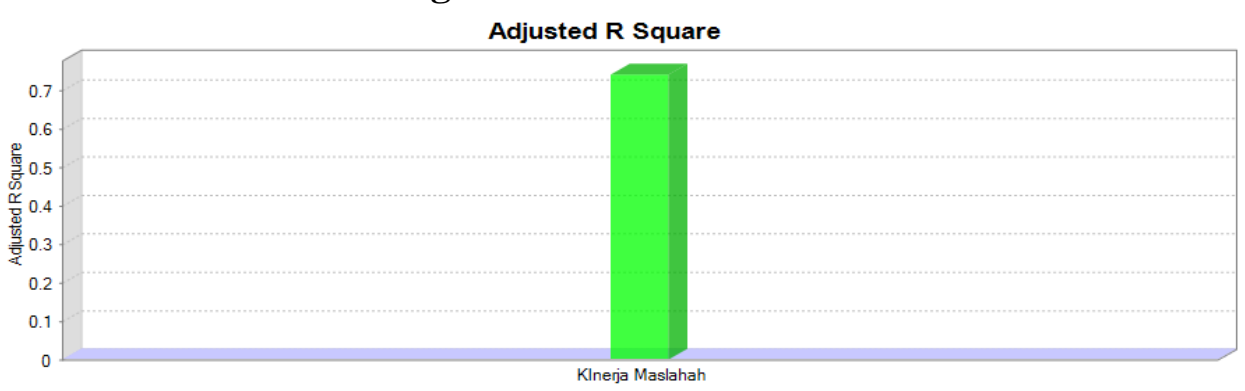

Source: 2021 primary data processed from SmartPLS 3

The R-Square bar chart image above obtains a path model $=0.797$, with a green diagram showing that the R-Square value is within the tolerance value.

\section{2). F-Square}

Table 4.6 Table F Square

\begin{tabular}{|c|c|}
\hline Variable & Maslahah Performance \\
\hline & \\
$\begin{array}{c}\text { Cognitive Aspects of } \\
\text { HR }\end{array}$ & $\mathbf{2 , 9 8 9}$ \\
\hline
\end{tabular}

Source: 2021 primary data processed from SmartPLS 3.

Based on the F-Square value in the table above, it can be concluded that the influence of the exogenous variable of the Cognitive Aspect of HR on the endogenous variable of Madalahah Performance is 2,989 classified as substantial or strong. The Composite Reliability diagram can be seen through the following diagram:

Figure 4.3 


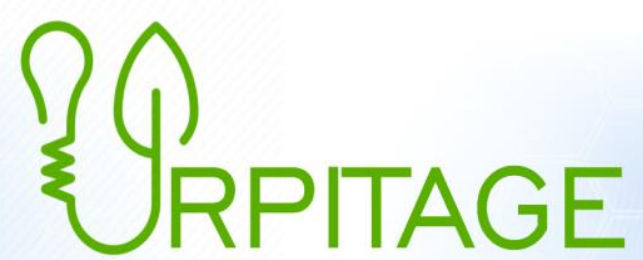

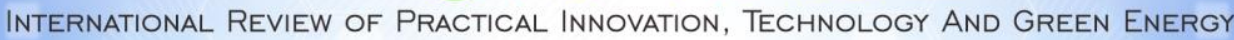

The F-Square bar chart image above shows that the $\mathrm{X}$ variable (Human Resources Cognitive Aspect) has an influence of 2,989 on the Y variable (Maslahah performance) which is included in the Substantial influence category, it can be seen that the green graph that passes through the intersection point indicates that the effect is in the tolerance.

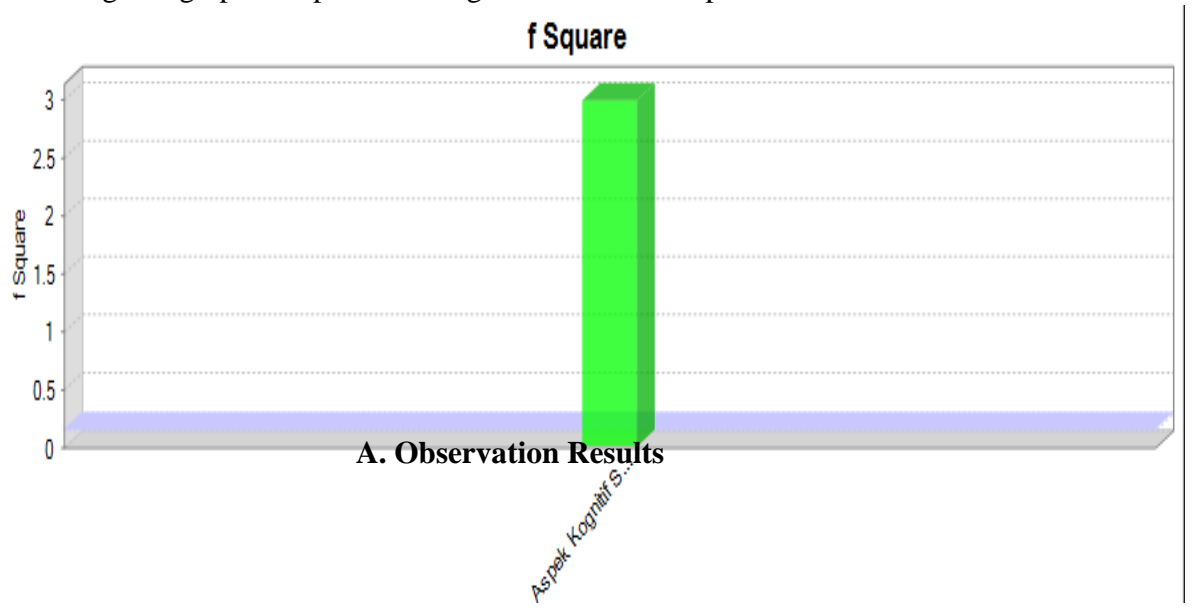

Observations were made to collect data on the activities of the existing BUMDes management system in the Sei Bamban district. This observation is used to obtain information about the findings obtained quantitatively and qualitatively. Doing documentation and observation. Observations were made 5 times to collect information about the potentials that exist in each village and observe the management of BUMDes. The summary of the results of the documentation is as follows:

1) Ranch

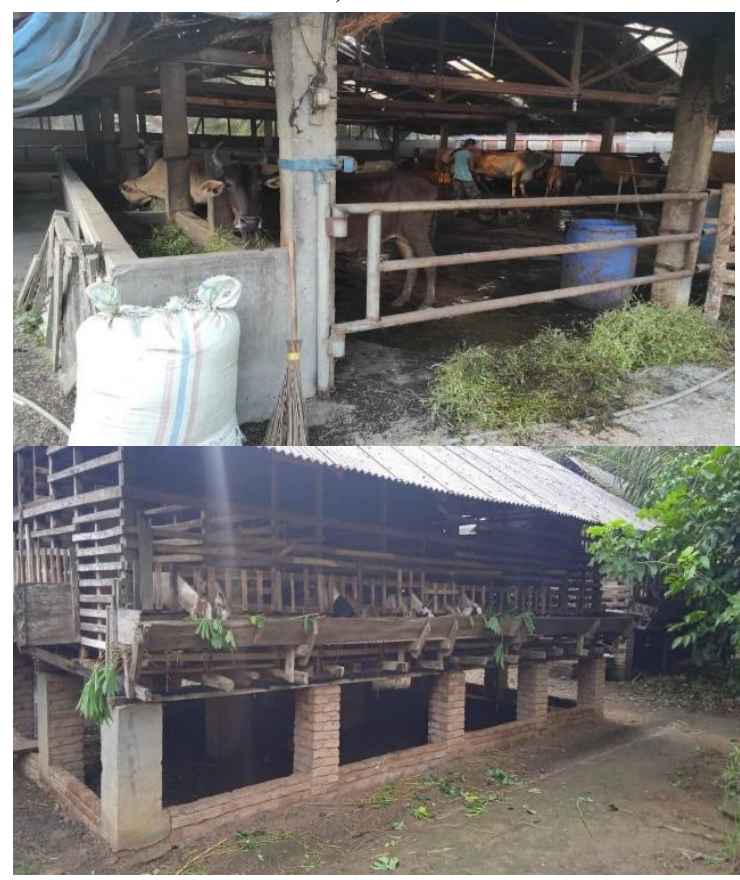

Goat and cattle farming is one of the potentials in Sei Bamban subdistrict, because it is surrounded by plantation areas making it easier for farmers to find animal feed. The number of people who depend on this animal husbandry can become a regional potential in supplying meat 
and livestock.

2) Agriculture

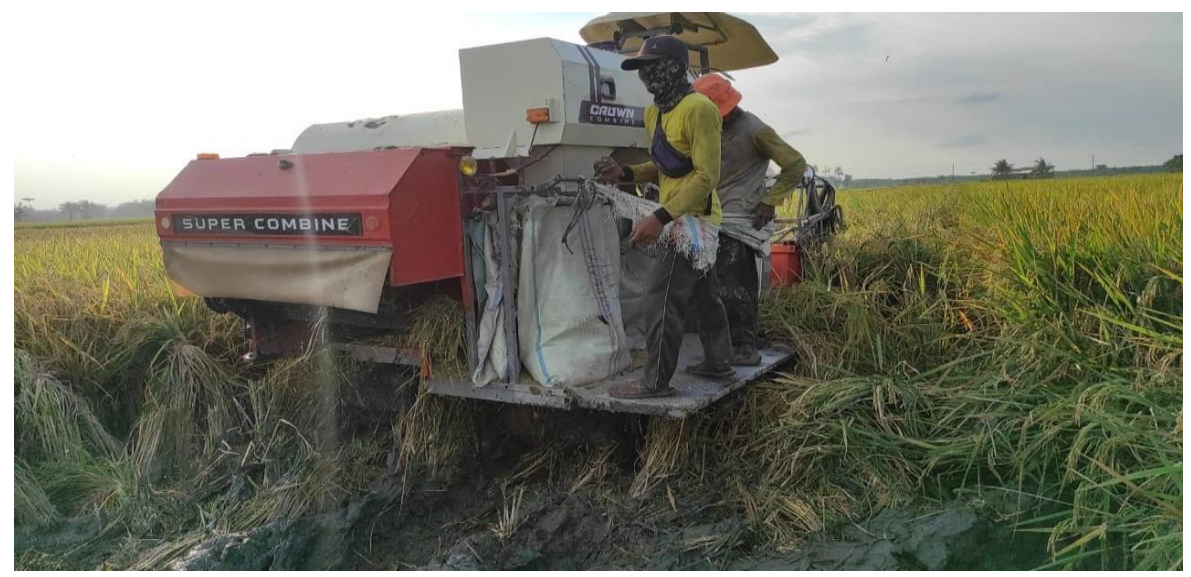

Rice farming is the majority of the work occupied by the people of the Sei Bamban sub-district, which is a lowland stretching area of agricultural land, especially rice, which is one of the potentials in the area. Not only rice, there are also vegetable and melon farmers.

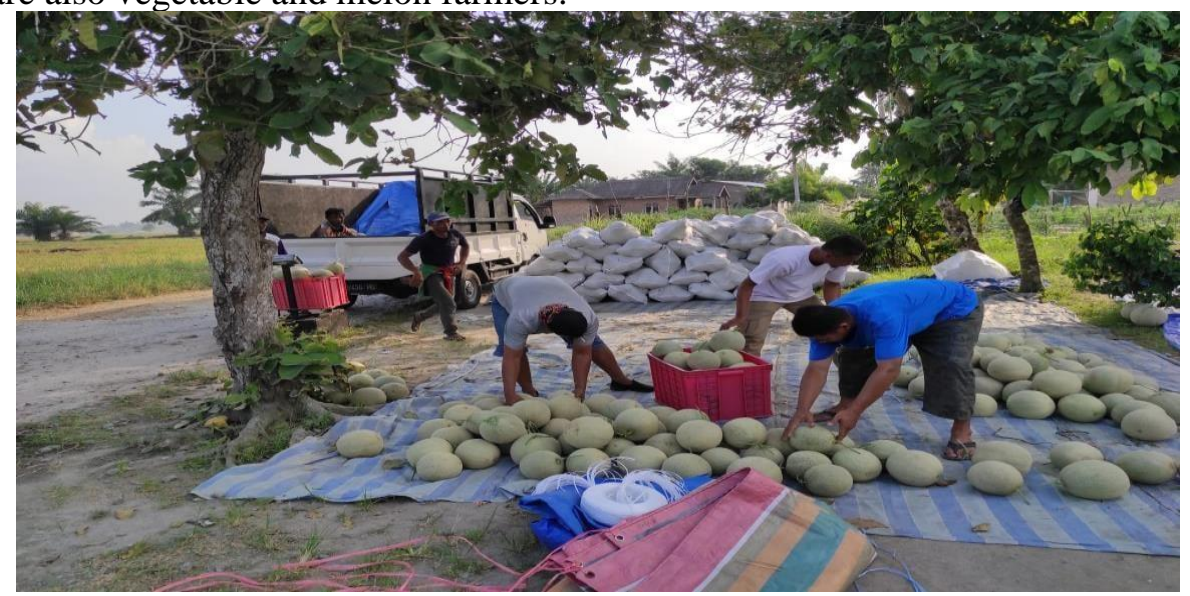

3) Plantation

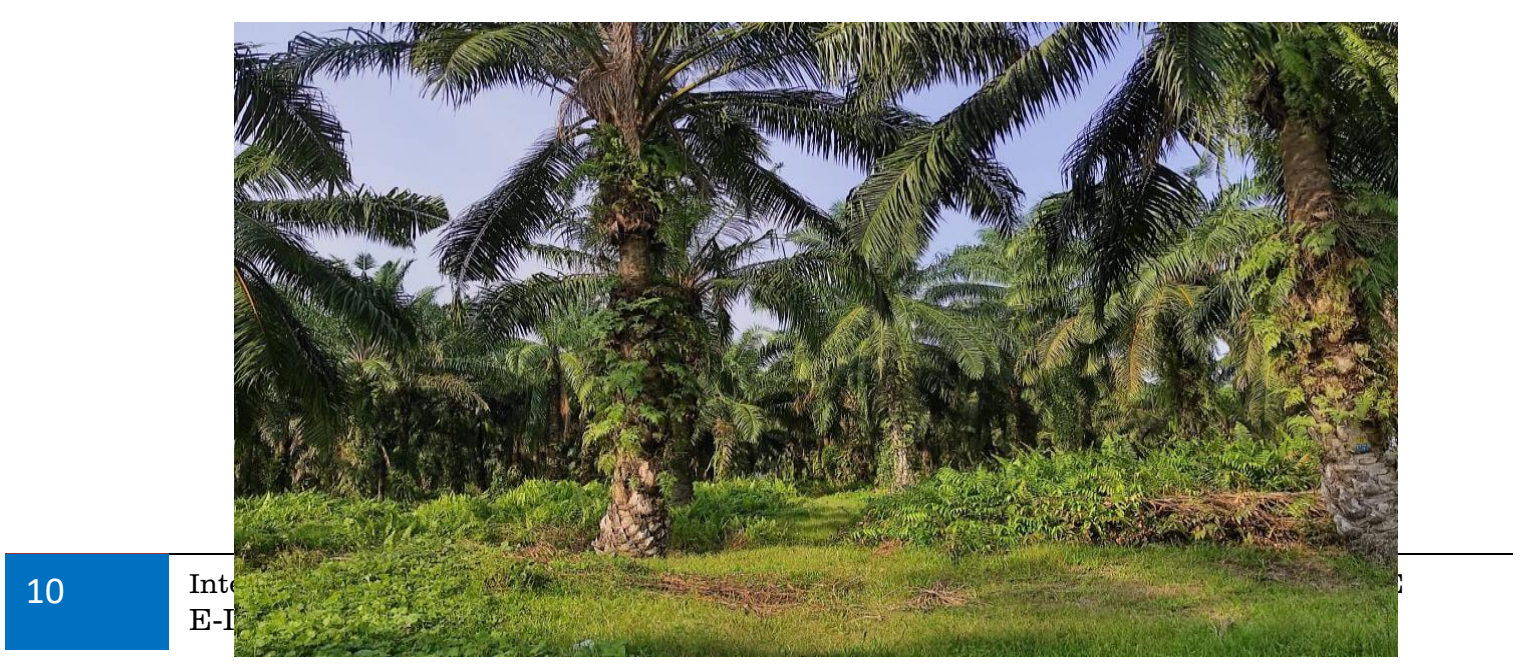




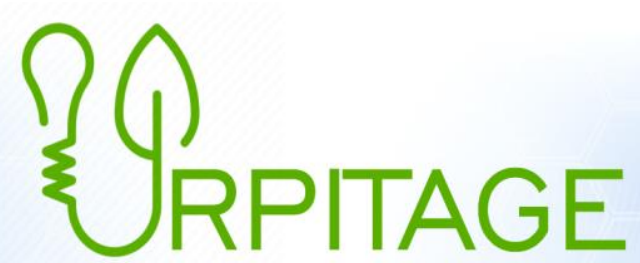

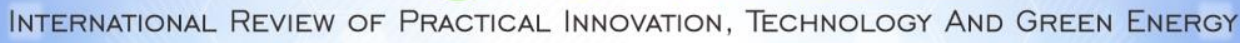

The Sei Bamban sub-district area is one of the sub-districts surrounded by plantations and there are several plantation villages in the area. People who live in the stout plantation area take advantage of such as raising livestock and becoming stick broom craftsmen by utilizing the harvested palm tree midrib leaves.

4) BUMDes

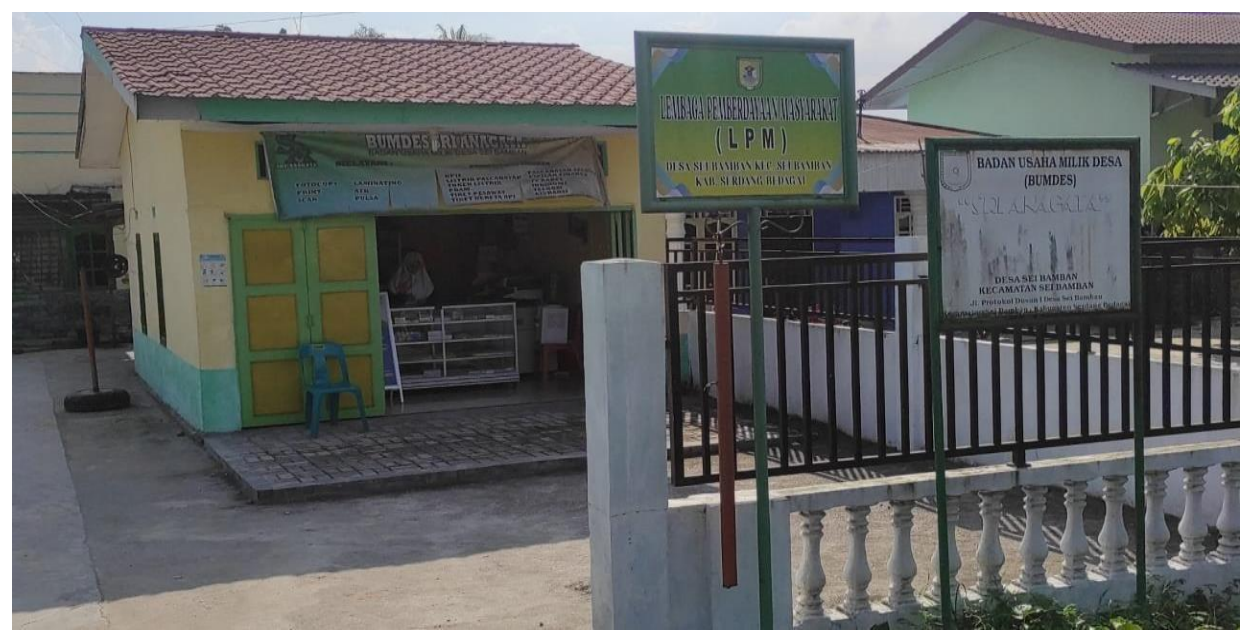

In the Sei Bamban sub-district there are several BUMDes but some of them have experienced bankruptcy and are no longer operating.

\section{CONCLUSION}

Based on the results of the R Square and F Square regression tests, it can be seen that the ability of the Cognitive Aspects of HR in explaining Maslahah Performance is $74 \%$ and there is an influence with the model classified as Substantial (strong) between the cognitive aspects of HR on the performance of BUMDes which is oriented to the benefit of the community. It can be concluded that the indicators of the cognitive aspects of HR, namely Knowledge, Understanding, Application, analysis and evaluation have an important role in optimizing organizational performance. Based on the statistical description on the Cognitive aspect of HR variables above, it can be interpreted that the BUMDes employees in the Sei Bamban district have good cognitive aspects. Because the results of the average score of the instrument from the hereditary variable is $76.36 \%$ which is included in the effective category because it is $>60 \%$. Likewise with the maslahah performance variable, it can be interpreted that BUMDes employees in the Sei Bamban district have good problem performance. Because the results of the average score of the instrument from the hereditary variable is $71.28 \%$ which is included in the effective category because it is $>60 \%$. The evaluation that needs to be improved in the management of BUMDes in the Sei Bamban district is on the cognitive aspect of $\mathrm{HR}$, namely the potential Basic management indicator which is not optimal at only $72.6 \%$, so that it can be improved again. asset management and village potential has the lowest score of $60.6 \%$, this value is low even though it is effective. It can be concluded that the performance of BUMdes in the Sei Bamban district has an effective category. 


\section{REFERENCE}

Agunggunanto, EY, Arianti, F., Kushartono, EW, \& Darwanto. (2016). Independent Village Development Through Village Owned Enterprise Management (BUMDes). Journal of Economic \& Business Dynamics, 13(1), 67-81.

Chikamawati, Z. (2015). The Role of BUMDes in Improving Rural Economic Growth through Strengthening Human Resources. JP Journal \& Proceeding Feb UNSOED , Volume 5, No. 1.

Coristya Berlian Ramadana, HR (2013). The existence of a Village Owned Enterprise (BUMDES) as a Village Economic Strengthener. Journal of Public Administration (JAP), Volume 1, No.6.

Dewi, AS (2014). The Role of Village-Owned Enterprises (BUMDES) as an Effort in Increasing Village Original Income (PADES) and Growing the Village Economy. Journal Of Rural and Development, Volume 5, No. 1.

Nursetiawan, I. (2018). Independent Village Development Strategy Through BUMDes Innovation. Moderate: Scientific Journal of Government Science, Volume 4, No.2.

Minister of Village Regulation, (2018). Development of Disadvantaged Regions, and Transmigration of the Republic of Indonesia number 16 of 2018 concerning Priority for the Use of Village Funds in 2019. Indonesia: KEMENDES PDTT

Retrieved fromhttps://ejournal.unisnu.ac.id/JDEB/article/viewFile/395/753

Ruslan, Rosyadi. (2004) Research Methods for Public Relations and Communication, Jakarta: Raja Grafindo Persada.

Soleh, A. (2017). Village Potential Development Strategy. Sungkai Journal, Volume 5, No.1.

Syafrizal, R. (2019). Performance Analysis of Islamic Human Resources Based on the Maslahah Scorecard Method (Case Study at Pt. Inalum). Journal of AT-Tawassuth, Volume 4, No.2.

Ulul Hidayah, SM (2019). Evaluation of Village Owned Enterprises (BUMDes): Case Study of BUMDes Harapan Jaya Pagelaran Village, Ciomas District, Bogor Regency. JSHP (Journal of Social Humanities and Education), Volume 3. No. 2.

Zulkarnaen, RM (2016). Development of Village Economic Potential through Village Owned Enterprises (BUMDES) Pondok Salam, Purwarkarta Regency. Dharmakarya: Journal of Science and Technology Applications for Society, Volume 5, No.1. 